\title{
Occurrence of vivianite in alluvial Quaternary sediments in the area of Sesvete (Zagreb, Croatia)
}

\author{
Anita Grizelj ${ }^{1}$, Koraljka Bakrač ${ }^{1}$, Marija Horvat ${ }^{1}$, Radovan Avanić ${ }^{1}$ and Ivan Hećimović ${ }^{2}$ \\ ${ }^{1}$ Croatian Geological Survey, Sachsova 2, 10000 Zagreb, Croatia; (grizelj.anita@hgi-cgs.hr) \\ ${ }^{2}$ Anina 29, 10000 Zagreb, Croatia
}

doi: $10.4154 / g c .2017 .01$

\section{Article history: \\ Manuscript received August 09, 2016 Revised manuscript accepted November 17, 2016 Available online February 20, 2017}

Keywords: vivianite, Quaternary sediments alluvial, informal Bistra Formation, Zagreb, Croatia

\begin{abstract}
Boreholes Badel-1 and Badel-2, located in Sesvete near Zagreb, were drilled through 71.50 and $84.40 \mathrm{~m}$ of Quaternary sediments, respectively. Within these sediments, the occurrence of earthy aggregate and 1-2 mm nodules of the deep blue coloured mineral vivianite was observed. Interpretation of the depositional environment, provenance of the sediments and vivianite occurrence was based on sedimentological, mineralogical and palynological analyses. Three different facies within the alluvial environments were interpreted:

1) gravels and sands typical of alluvial environments

2) structureless beds of silts and clays deposited in oxbow lakes, marshes and floodplains

3) chaotic sediments deposited in the upper part of the alluvial fan.

Macroscopically, an earthy aggregate is essentially an occurrence of flattened vivianite crystals grouped in clusters. The studied sediments are the product of intensive weathering of different types of rocks from Medvednica Mt. with a prevalence of green-schists. Rocks from Medvednica Mt. as the source of ferrous iron $\left(\mathrm{Fe}^{2+}\right)$ and phosphorus $(\mathrm{P})$, and reductive depositional environments can indicate conditions for genesis of vivianite.
\end{abstract}

\section{INTRODUCTION}

Quaternary sediments from the Zagreb area were studied in many aspects during the last century (e.g. GORJANOVIĆKRAMBERGER, 1907; CRNKOVIĆ \& BUŠIĆ, 1970; ŠIMUNIĆ \& BASCH, 1975; S̆IMUNIĆ et al., 1988; VELIĆ \& DURN, 1993; ŠIKIĆ, 1995; VELIĆ et al., 1995; VELIĆ et al., 1999), but they are shown most completely on the Basic Geological Map of SFRY, 1:100.000, sheet Ivanić Grad (BASCH, 1983a, 1983b). Pleistocene deposits are represented by aeolian and aquatic-aeolian sediments while in the Holocene, deposits are dominated by alluvial and subordinately by deluvial-proluvial sediments. Marsh sediments are less abundant. Similar distinctions of these sediments are applied on the Geological Map of the Republic of Croatia $1: 300.000$ (2009).

Similar sediments are described by AVANIĆ et al. (2006) from the outcrop near Vojnić (Fig. 1A), and consist of silts, clays, gravels and sands which were deposited in an alluvial environment and belong to the informal Bistra Formation. The chronostratigraphic position of this formation is still under debate due to the lack of absolute dating evidence. AVANIĆ et al. (2006) suggest that the Bistra Formation spans a Pliocene-Pleistocene age.

During mapping for the Basic Geological Map of the Republic of Croatia at 1:50.000 scale, two boreholes: Badel-1 (45 $82^{\prime} 64^{\prime \prime} \mathrm{N}$; $\left.16^{\circ} 09^{\prime} 98^{\prime \prime} \mathrm{E}\right)$ at $71.50 \mathrm{~m}$ deep and Badel-2 (45 $\left.82^{\prime} 67^{\prime \prime} \mathrm{N} ; 16^{\circ} 10^{\prime} 09^{\prime \prime} \mathrm{E}\right)$ at $84.40 \mathrm{~m}$ were studied in the area of the former „Badel” factory in Sesvete (Fig. 1). On this map, Quaternary sediments are subdivided on the basis of their lithology. In the Pleistocene, silts, clays, sands and gravels of the informal Bistra Formation (BS) are dominant while in the Holocene-Pleistocene, sands and gravels of the second terrace $\left(t_{2}\right)$ are present. The Holocene is represented by (a) silts and clays of marsh environments and (b) sands, silts and gravels of alluvial environments. Within the investigated sediments of the boreholes, the deep blue mineral vivianite was observed (Figs. 3, 4A). Vivianite $\left(\mathrm{Fe}_{3}\left(\mathrm{PO}_{4}\right)_{2} \times 8 \mathrm{H}_{2} \mathrm{O}\right)$ is a ferrous iron phosphate mineral which forms in waterlogged soils and aquatic sediments (BERNER, 1981; BERMANEC, 1999; ROTHE et al., 2014, 2016). It is probably the most stable $\mathrm{Fe}^{2+}$ orthophosphate mineral in sedimentary environments and in natural systems, stable under $\mathrm{pH}$ conditions from 6 to 9 (NRIAGU, 1972). The precipitation of vivianite often occurs directly from the pore water which contains high concentrations of ferrous iron $\left(\mathrm{Fe}^{2+}\right)$ and soluble reactive $\mathrm{P}$ which is found in anoxic non-sulfidic environments (NRIAGU, 1972; RODEN \& EDMONDS, 1997).

The aim of this article is to determine the sedimentological and mineralogical characteristics of alluvial Quaternary sediments in the area of Zagreb where vivianite occurs.

\section{GEOLOGICAL SETTINGS}

The North Croatian Basin is the south-western part of the Pannonian Basin System (PBS) (PAVELIĆ, 2001) which comprises the biggest part of the Central Paratethys realm (HARZHAUSER \& PILER, 2007). Medvednica Mt., is a neighboring mountain to the study area (Fig. 2), and represents one of the inselbergs in the PBS which exposes Palaeozoic-Mesozoic rocks deformed during Cretaceous-Palaeogene times and surrounded by Miocene sediments (TOMLJENOVIĆ et al., 2008). Tectonically, it is located in the Zagorje-Mid-Transdanubian shear Zone (ZMTDZ) segment of the Sava Zone. This part of the Sava Zone is the area of the connection between the Southern-Eastern Alps, Tisia block of the PBS and the Internal Dinarides (PAMIĆ \& TOMLJENOVIĆ, 1998; HERAK, 1999; HAAS et al., 2000; HAAS \& KOVÁCS, 2001; PAMIĆ 2002, 2003).

The core of Medvednica Mt. is composed mostly of a variety of metamorphic rocks such as metapelites, metapsammites, slatephyllites, slates, quartzites, marbles, blueschists, greenschists of Palaeozoic age and more rarely of Mesozoic age (BELAK et al., 
A

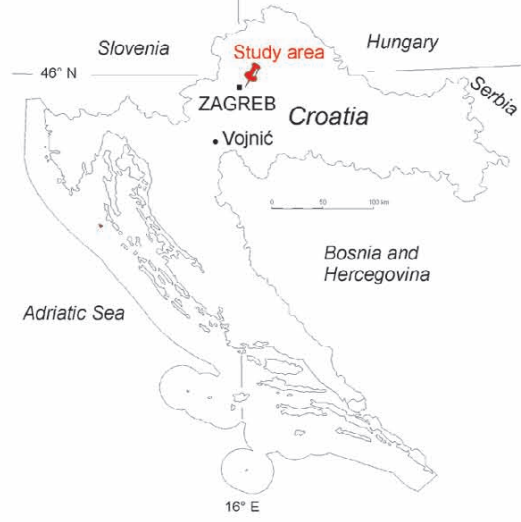

\section{Legend:}

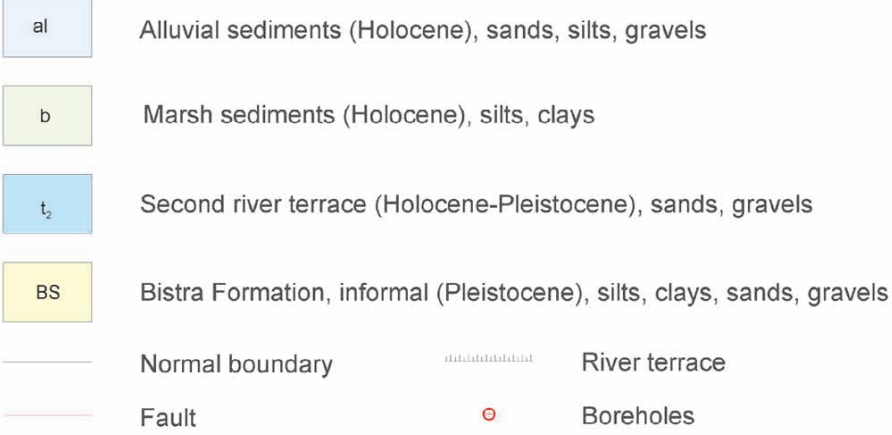

B

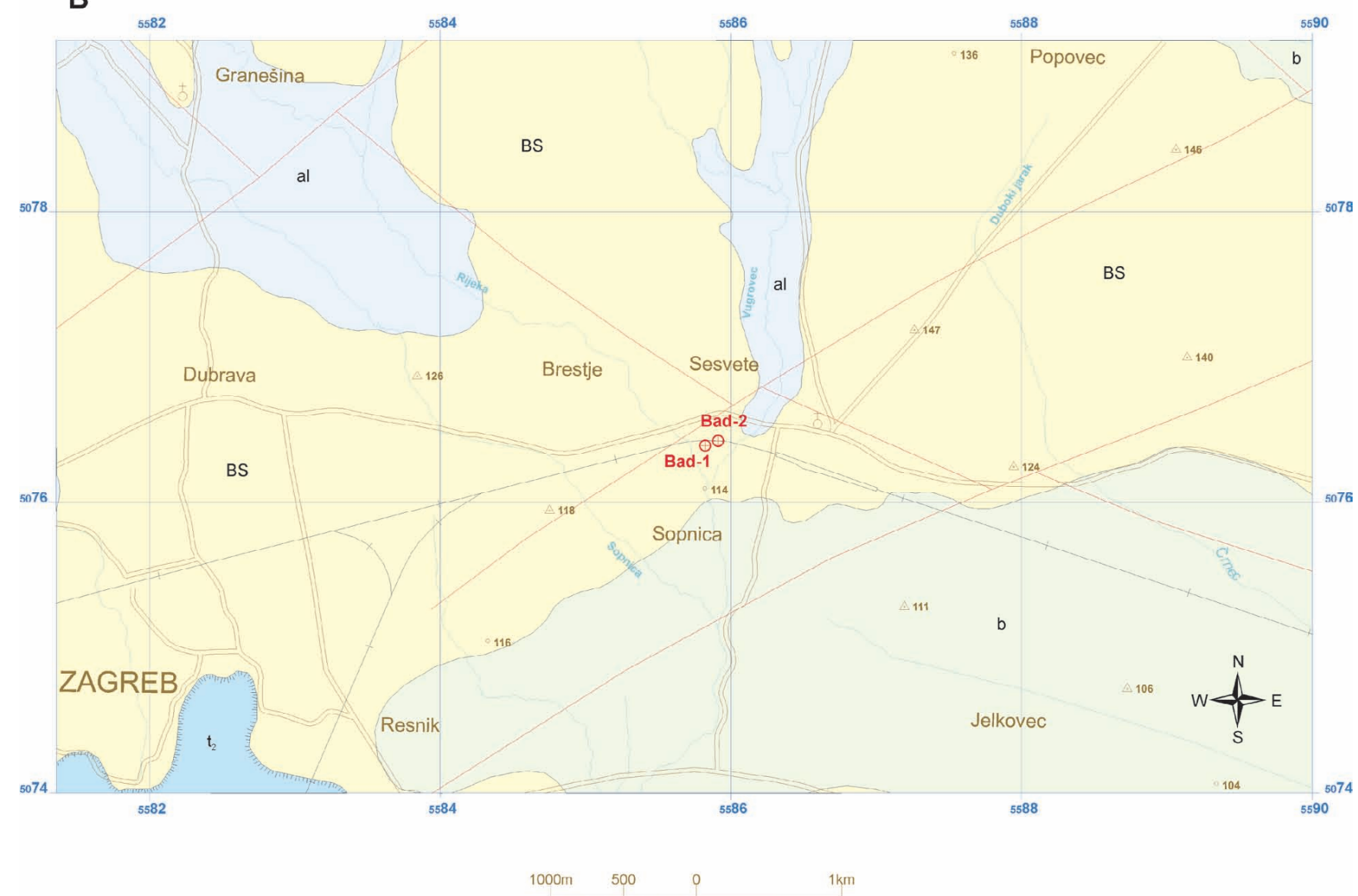

Figure 1. A) Location map and, B) Lithostratigraphic geological map of the Sesvete area with locations of boreholes Badel-1 (Bad-1, $\left.45^{\circ} 82^{\prime} 64^{\prime \prime} \mathrm{N} ; 16^{\circ} 09^{\prime} 98^{\prime \prime} \mathrm{E}\right)$ and

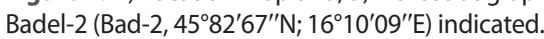

1995, BELAK \& TIBLJAŠ, 1998; LUGOVIĆ et al., 2006; TOMLJENOVIĆ et al., 2008). Mafic extrusive rocks occasionally intersected by dolerite dykes represent the most abundant fragments of oceanic crust in the Early Callovian to Late Valanginian ophiolite mélange exposed at Medvednica Mt. (SLOVENEC \& LUGOVIĆ, 2009). Metamorphic and non-metamorphic rocks are generally in tectonic relationships except for Upper Cretaceous and Tertiary sediments which are transgressive. The most common Mesozoic rocks are limestones and dolomites (BASCH, 1983b; ŠIKIĆ et al., 1979; ŠIKIĆ, 1995). Subordinately, during the Mesozoic different clastic sedimentary rocks, radiolarian cherts and, occasionally, pyroclastic and magmatic rocks also oc- curred (HALAMIĆ \& GORIČAN, 1995; HALAMIĆ et al., 1999; BABIĆ et al., 2002; SLOVENEC \& LUGOVIĆ, 2008, 2012).

The formation of the PBS commenced in the Early Miocene due to continental collision and subduction of the European Plate beneath the African (Apulian) Plate. It is surrounded by the Alpine, Dinaric and Carpathian mountain belts (Fig. 2) and includes a number of different-sized deep depressions (sub-basins) separated by a comparatively shallow complex of basement rocks (HORVÁTH \& ROYDEN, 1981; ROYDEN, 1988). The development of the PBS took place in two phases. The Early and Middle Miocene syn-rift phase of basin development was characterized by tectonic thinning of the crust and isostatic subsidence, while 


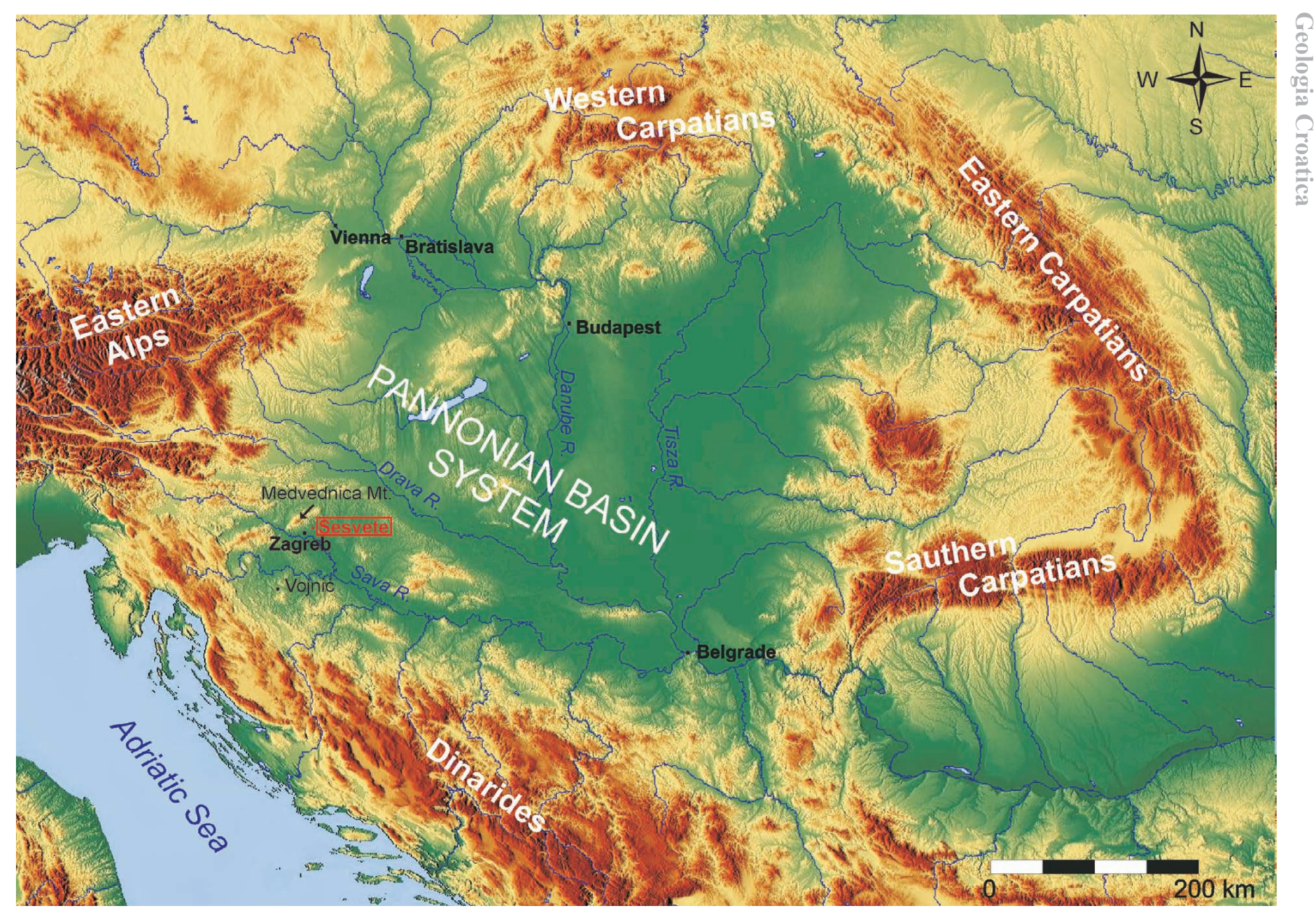

Figure 2. Pannonian Basin System (PBS) and its surroundings with the locations of the study-area marked in red. Based on http://maps-for-free.com/.

the Middle and Upper Miocene post-rift phase was marked by subsidence caused by cooling of the lithosphere (HORVÁTH \& ROYDEN, 1981; ROYDEN et al., 1983; ROYDEN, 1988, PAVELIĆ, 2001).

The evolution of Neogene sedimentation on Medvednica Mt. was described in detail by PAVELIĆ et al., 2003; AVANIĆ et al., 2003; BASCH, 1983a, 1983b; ĆORIĆ, et al., 2009; HERAK, 2006; KOVAČIĆ \& GRIZELJ, 2006; GRIZELJ et al., 2017; ŠIKIĆ et al., 1977; 1979; ŠIKIĆ, 1995; VRSALJKO, 1999; VRSALJKO et al., 2006; BRLEK et al., 2016. According to the aforementioned authors, Early Miocene sediments unconformably overlie tectonised Palaeozoic-Mesozoic crystalline basement. During the Miocene, various types of clastic sediment and limestones were deposited in different marine, brackish and freshwater environments depending on the PBS development. Pliocene and Quaternary sediments consist of clays, silts, sands and gravels which were deposited in freshwater lakes, swamps and fluvial environments.

\section{METHODS}

Field work included the following: measurement of the thickness of the deposit, defining the type of contacts between intervals, determining the type of sediments and sampling for grain-size analysis (14 samples), mineralogical-petrological and palynological analysis. Mineralogical-petrological analysis included the following: microscope analysis of unconsolidated sedimentary rocks (16 samples), X-ray powder diffraction (XRPD), SEM-EDS analysis of vivianite (1 sample) and measurement of $\mathrm{CaCO}_{3}$ (14 samples).
Grain size analyses were performed using a combination of sieving and aerometric methods. The nomenclature according to TREFETHEN (1950) and KONTA (1973) was used for the classification of sediments.

Preparation for qualitative and quantitative mineralogical analyses of the light and heavy mineral fraction of silty and sandy samples included the following: carbonate fraction dissolution with $4 \%$ cold hydrochloric acid, separation of the $0.09-0.045 \mathrm{~mm}$ mineral fraction from the sandy and silty sediments using sieves, separation of the heavy and light mineral fraction using bromoform $\left(\mathrm{CHBr}_{3} ; \delta=2.84 \mathrm{gcm}^{-3}\right)$. Analyses were performed by determination of 300-400 grains per sample using the ribbon counting method according to MANGE \& MAURER (1992).

Preparation of coarser sand and fine gravel samples included separation by sieves $2.80 \mathrm{~mm}, 1.25 \mathrm{~mm}$ and $0.90 \mathrm{~mm}$ fraction.

For XRPD analysis, individual grains of vivanite were separated using a stereomicroscope and needle. XRPD patterns were recorded on a Philips vertical goniometer (type X'Pert) equipped with a $\mathrm{Cu}$-tube using the following experimental conditions: 45 $\mathrm{kV}, 40 \mathrm{~mA}$, PW 3018/00 PIXcel detector, primary beam divergence $1 / 4^{\circ}$ and continuous scan (step $0.02^{\circ} 2 \theta / s$ ).

SEM-EDS analysis was carried out on the JEOL Multi-Purpose scanning microscope (JSM-35). Morphologic analyses were performed at $20 \mathrm{keV}$ accelerating potential and $90-\mathrm{mA}$ filament current. Compositional analyses by energy dispersive spectrometry (EDS) utilized a liquid nitrogen cooled INCAx-act Oxford Instruments detector with the microscope operating at $20-\mathrm{keV}$ 


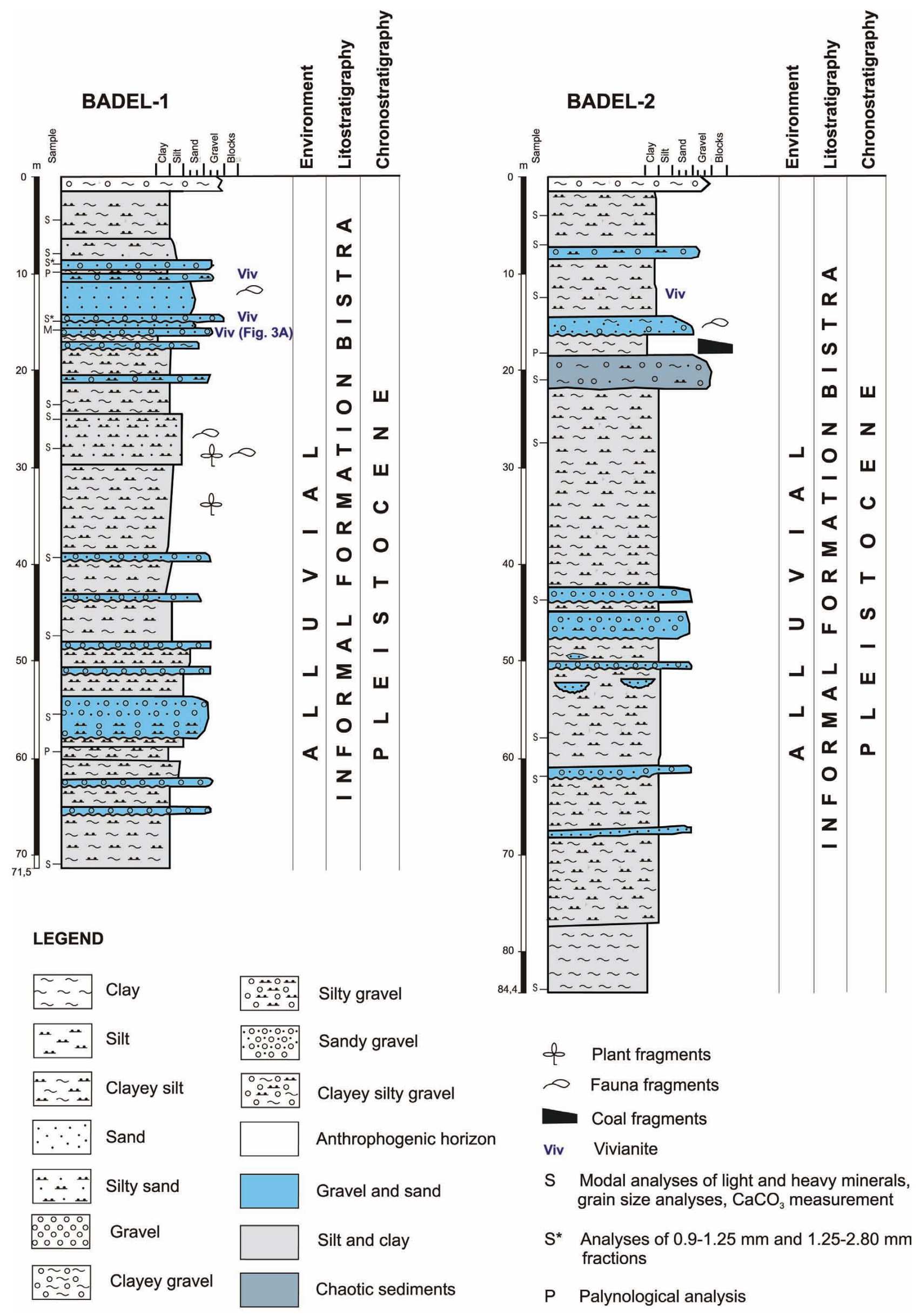



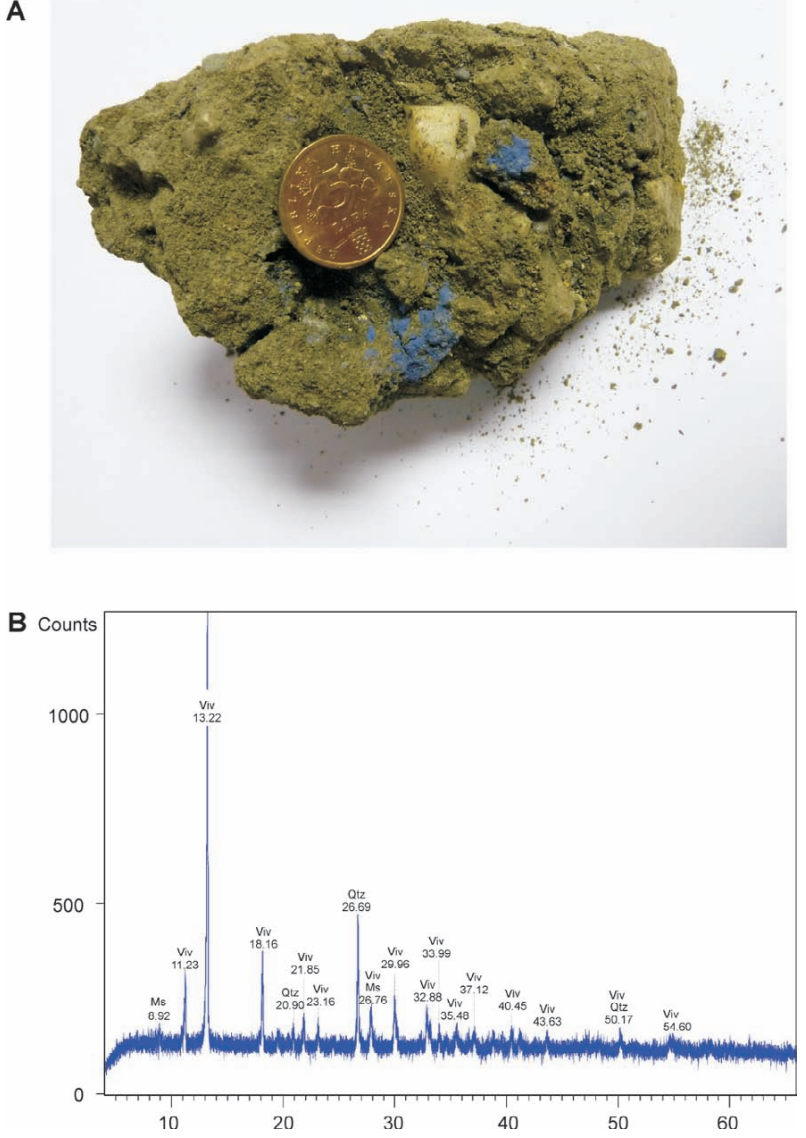

C

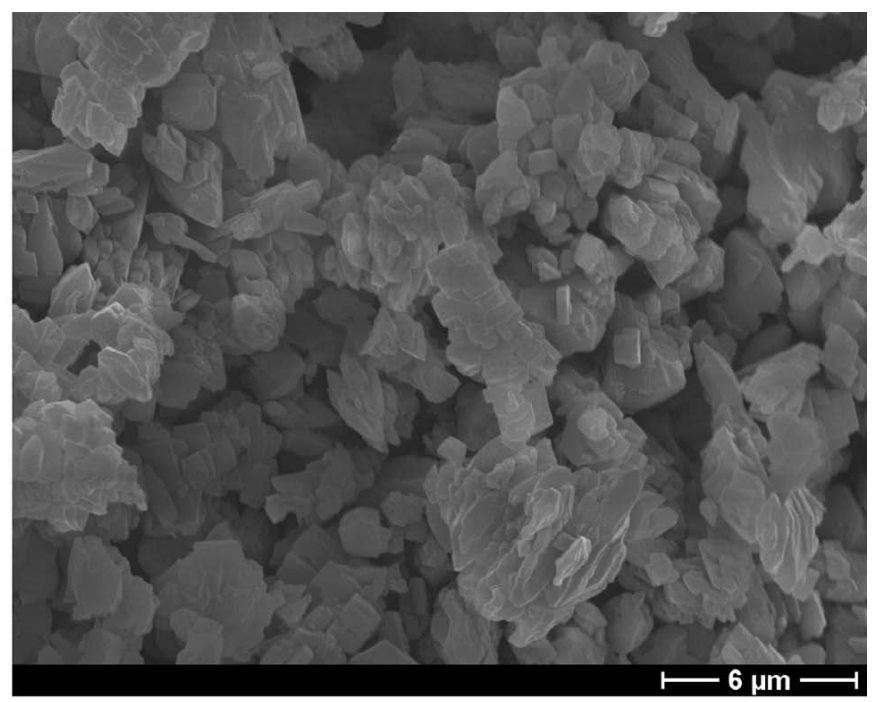

D

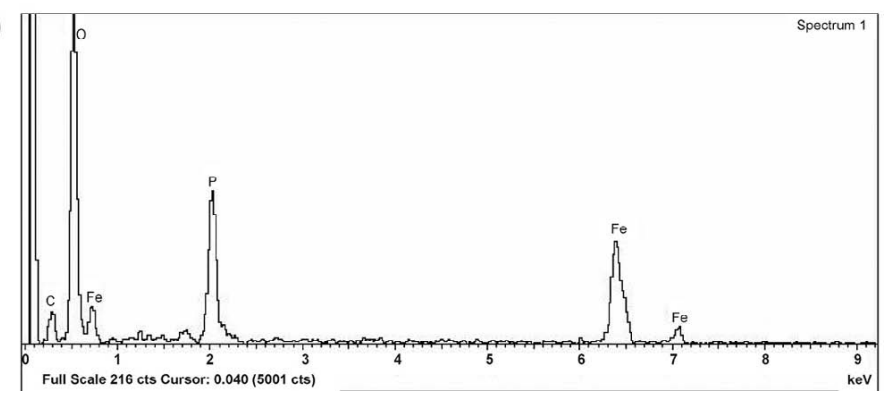

Figure 4. Vivianite from sample Bad-1/14.60-15.20 m; A) photo showing a mineral aggregate in sediment, B) XRPD pattern of the separated material (Viv - vivianite, Qtz - quartz, Ms - muscovite), C) SEM image - flattened crystals up to $6 \mathrm{~mm}$ length, D) EDS spectrum of elemental analysis.

potential and $90-\mathrm{mA}$ current. $\mathrm{CaCO}_{3}$ was measured using the Collins calcimeter.

Standard palynological processing techniques (FAEGRI \& IVERSEN, 1989; MOORE et al., 1991) were used to extract the organic matter. The samples were treated with sodium pyrophosphate $\left(\mathrm{Na}_{4} \mathrm{P}_{2} \mathrm{O}_{7}\right)$, hydrochloric acid $(\mathrm{HCl}, 15 \%)$, and hydrofluoric acid (HF, $40 \%$ ), to remove the clay minerals, carbonates and silica, respectively, followed by separation of the organic residue by means of Zinc chloride $\left(\mathrm{ZnCl}_{2}\right.$, specific gravity 2.0). The residue was sieved at $10 \mu \mathrm{m}$ using a nylon mesh. Microscope slides were prepared using glycerin for palynofacies analysis, and with silicone oil for palynomorph analysis. Pollen identification was carried out under an Olympus BH-2 transmitted light microscope at x400, x600 and x1000 (oil immersion) magnifications combined with the interference contrast. Fluorescence was used in order to distinguish reworked palynomorphs. Photos were taken using a Moticam 2300. Palynological residues and slides are stored in the collection of the Croatian Geological Survey.

All analyses were made at the Croatian Geological Survey (Croatia, Zagreb).

\section{RESULTS AND DISCUSSION}

\subsection{Description and interpretation of facies}

Geological investigations consisted of petrographic and sedimentological determination of the boreholes, mineralogical investigation of vivianite and definition of a stratigraphic affiliation of the deposits based on palynological analyses. A detailed geological column of the investigated boreholes is shown in Figure 3. Vivianite was found at depths up to $15.20 \mathrm{~m}$ in sediments of the boreholes Badel-1 and Badel-2 (Figs. 1, 3, 4A). Drilled deposits are grouped into three facies: a) gravels and sands, b) structureless beds of silts and clays, and c) chaotic sediments.

\subsubsection{Gravels and sands facies}

Gravels and sands form decimetre to metre thick lenses and interbeds which overlie structurless silts and clays beds with an erosional lower boundary. In some interbeds, clast-supported gravels show the tendency of fining upwards, from fine-grained and sandy gravel in the lower part to silty and clayey sands in the upper part. The matrix is poorly sorted gravelly sand, silty sand or very rarely, silts. Pebbles are mostly 0.2 to $2 \mathrm{~cm}$ in diameter. Sands form interbeds from 0.5 to $6 \mathrm{~m}$ thick or lenses changing into interbeds of gravels. They are fine to coarse-grained, poorly sorted, and horizontally bedded. Within the gravelly sand, blue earthy aggregates and 1-2 $\mathrm{mm}$ size nodules of oxidizes vivianite were observed (Figs. 3 and 4A). Their presence was demonstrated by XRPD and EDS analyses (Fig. 4B and 4D). Macroscopically, earthy aggregate is essentially an occurrence of flattened vivianite crystals up to $6 \mu \mathrm{m}$ in size, grouped into clusters (Fig. 4C). The occurrence of vivianite is linked to oxidation-reduction reactions in sediments (ROTHE et al., 2016). It appears when pore waters have sufficiently high orthophospate and $\mathrm{Fe}^{2+}$ concentrations and $\mathrm{S}^{2-}$ is not present in high amounts (NRIAGU, 1972; ROTHE et al., 2015).

The grain size, clast-supported nature of the gravel, its poor sorting and the erosional lower boundary, together indicate high sediment concentration flows and deposition in stream channels (NEMEC \& STEEL, 1984). The associated sands are interpreted as having been deposited from sheetflows (NEMEC \& KA- 
ZANCI, 1999). The sandy matrix, upwards fining tendency and sandy lenses suggests deposition by a waning flow. Such frequent vertical and lateral changes of sand and gravel are typical of alluvial environments (MIALL, 1996, 2000).

\subsubsection{Facies of structureless beds of silts and clays}

Structureless beds of silts and clays overlie gravel and sand facies or the facies of chaotic sediments. They contain fragments of flora and fauna, coal and earthy vivianite aggregate (Fig. 3). Earthy aggregate of vivianite is sporadically present in the sediments at depths down to $15 \mathrm{~m}$ as a short linear zone or dots which are macroscopically visible. The $\mathrm{CaCO}_{3}$ content varies from 3.3 to $47.3 \%$ (Tab. 1). These sediments are poorly to very poorly sorted. Based on their $\mathrm{CaCO}_{3}$ content and grain size they are classified as clayey silts, calcareous clayey silts, silts, calcareous sandy clayey silts and calcareous sandy silts (Tab. 1). The grain size of silts and clays suggests that they were deposited from suspension on the flood plain. In association with coarse-grained alluvial facies, these sediments could be deposited in oxbow lakes and marshes, similar to Pliocene-Pleistocene sediments described nearby Vojnić (AVANIĆ et al., 2006).

\subsubsection{Facies of chaotic sediments}

Chaotic sediments are deposited on structureless silts and clays. The lower bedding plane is uneven. They are characterized by internal disorganization, poorly sorting, and a wide range of grain sizes, from coarse gravel to clay-sized particles. These characteristics of the deposits indicate a debris flow (NEMEC \& STEEL, 1984), which may point to a proximal alluvial fan, or to the outcome of a sudden destabilization of previously deposited unconsolidated material (NEMEC \& POSTMA, 1993).

\subsection{Content of heavy and light minerals}

Table 1. shows the results of modal analyses of the heavy and light mineral fractions from the sandy-silty fraction of samples (Fig. 3). Samples are dominated by grains from the light mineral fraction (LMF). Quartz is the most common mineral in the LMF and its content varies from 40 to $87 \%$. Grains with low undulatory extinction prevail while grains with homogeneous extinction are rare. The amount of rock fragments varies from 2 to $54 \%$. Among them, low-grade metamorphic schists are the most abundant. Chert, quartzite and tuffs are less abundant. The amount of $\mathrm{K}$-feldspars varies from 2 to $12 \%$. Muscovite is present in a very small quantity in almost all samples (Tab. 1). Samples Bad-1/4.30 m and Bad-2/12.40 m contain a small amount of sponge spicules.

Translucent minerals prevail in the heavy mineral fraction (HMF) in all samples, followed by opaque minerals (magnetite and limonite), while chlorite is less abundant. Samples Bad1/25.00 $\mathrm{m}$ and Bad-2/62.00 m contain a small amount of biotite. Among the translucent minerals in the HMF the minerals from the epidote group (epidote, zoisite, clinozoisite) are dominant in most samples, ranging from 24 to $95 \%$ (Tab. 1). Epidote appears as allotriomorphic grains with weakly expressed pleochroism, with pale yellow to yellowish green colour (Fig. 5 A-E). Other significant minerals in the HMF (Tab. 1) are garnet (Fig. 5 B-E) and staurolite (Fig. 5 D). Garnet occurs as pale pink-coloured, irregular grains. Staurolite appears as allotriomorphic grains with noticeable pleochroism, in pale yellow to dark yellow colours. Tourmaline, zircon rutile, amphiboles and kyanite (Fig. 5) are present in almost all samples, while titanite, chloritoid, pyroxene and brookite are present in some samples (Tab. 1). Tourmaline (Dravite type) (Fig. 5 B) occurs in the form of allotriomorphic, rarely hypidiomorphic crystals with strong pleochroism, in dark brown to brown colours. Zircon appears as colourless, rounded

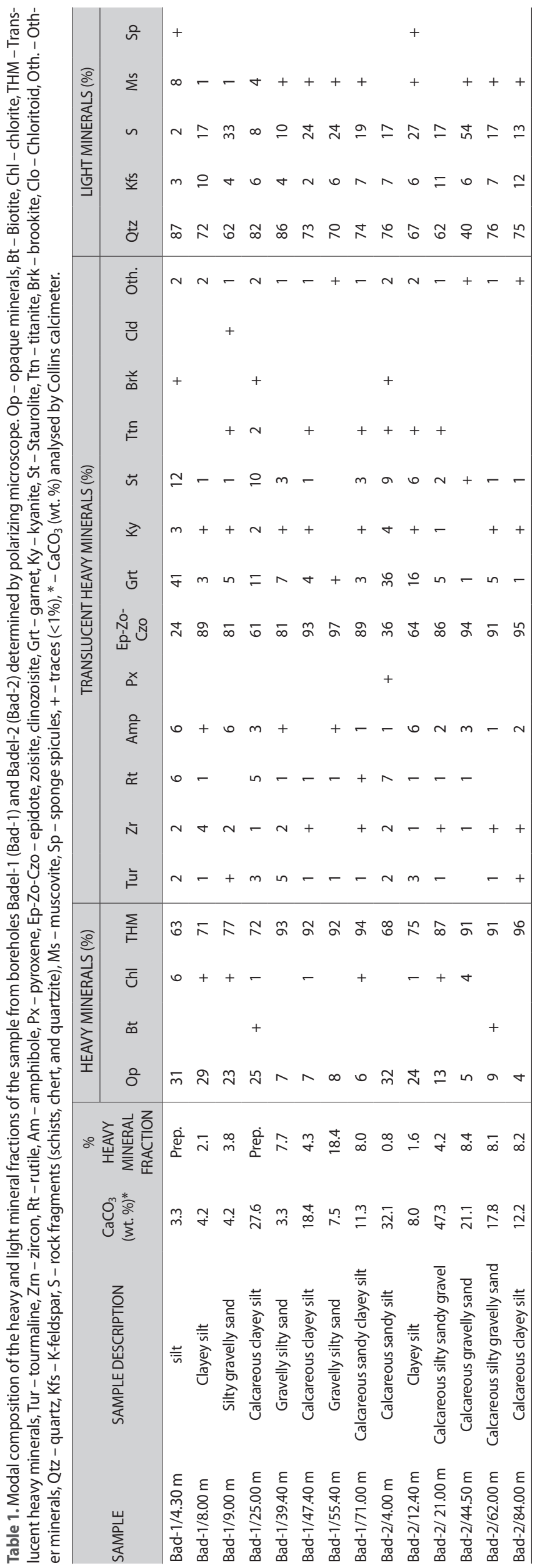




\section{A}

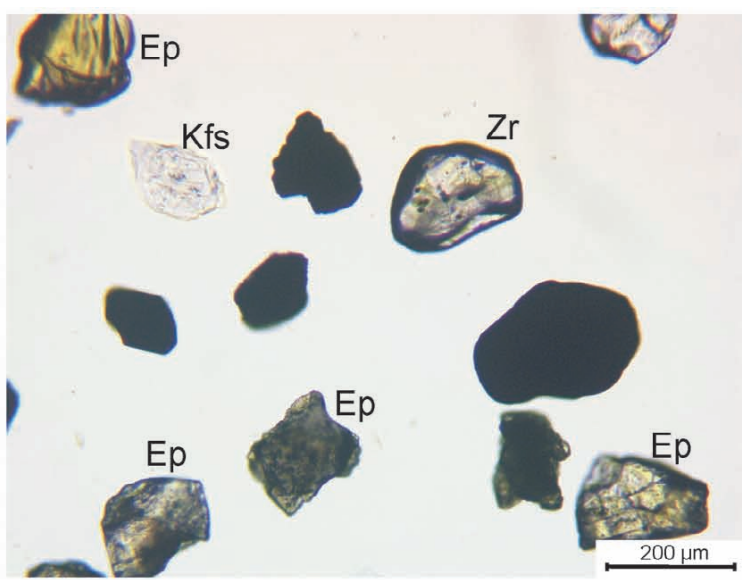

C

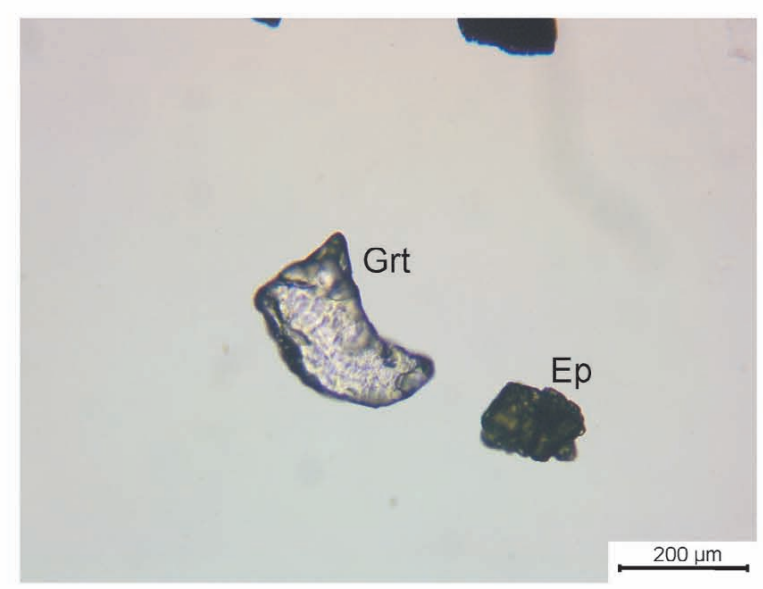

E

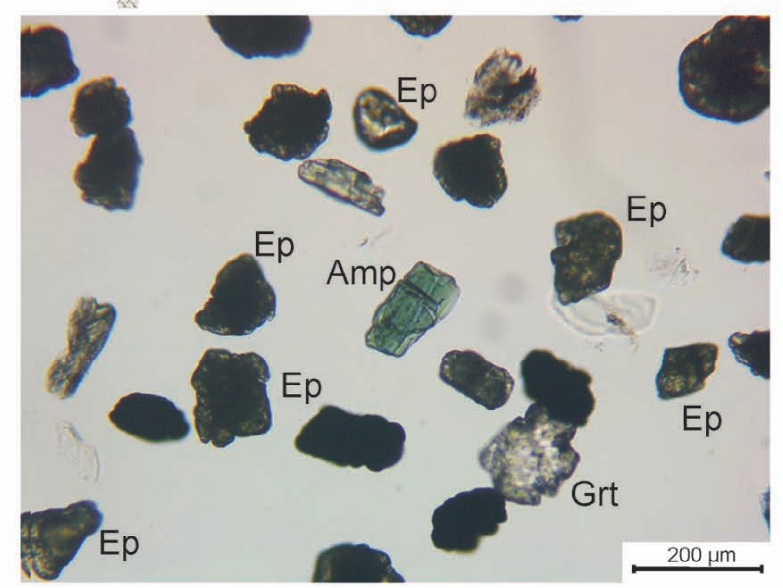

B

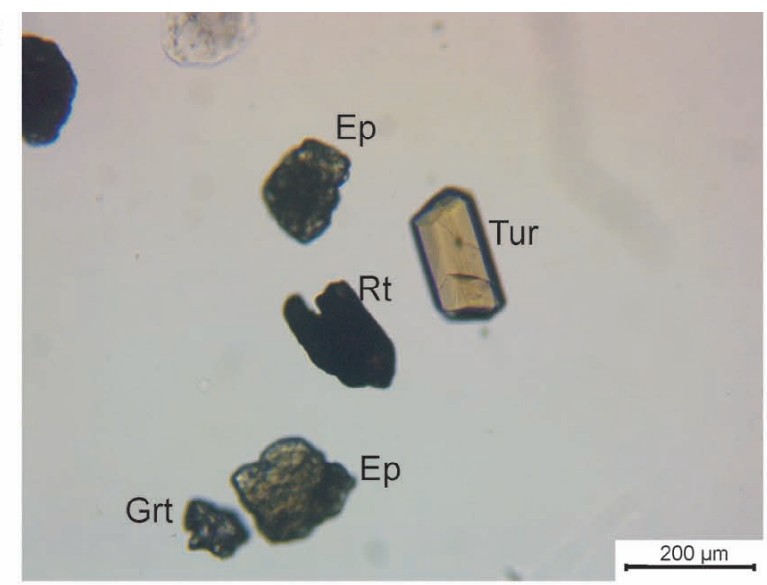

D

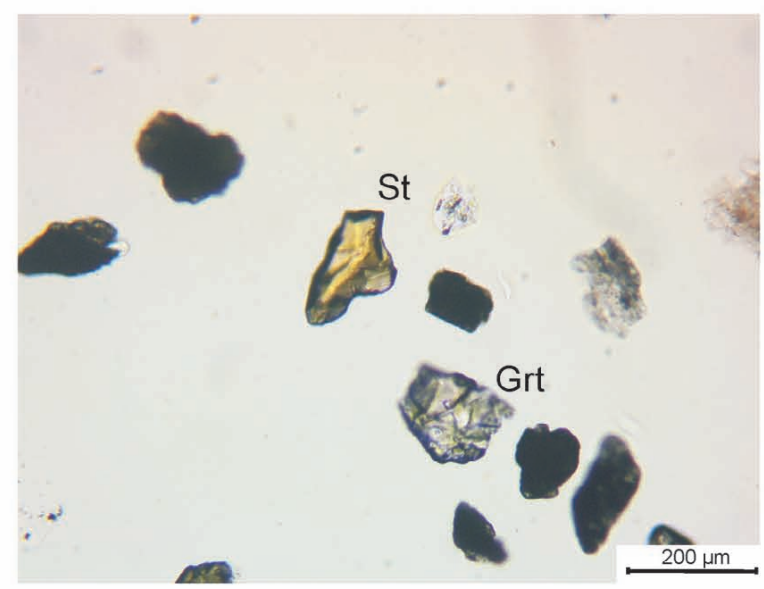

$\mathbf{F}$

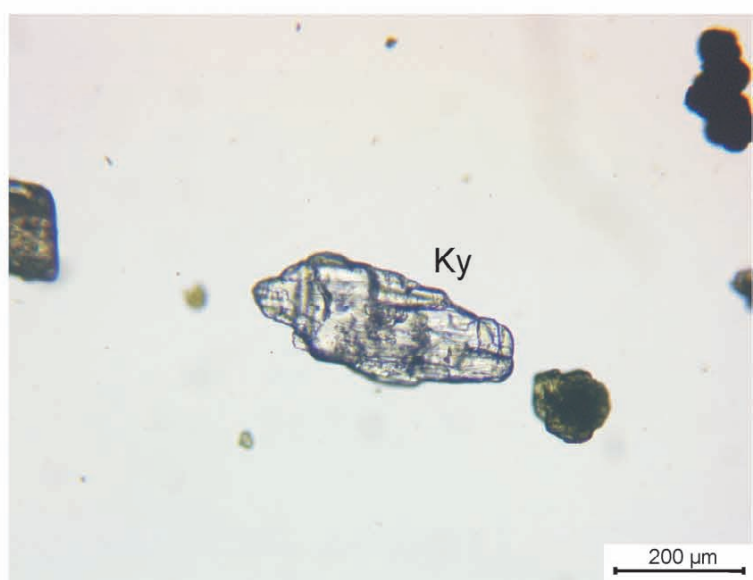

Figure 5. Photomicrographs of the Heavy mineral fraction: A, B, C) sample Bad-1/39.40 m, analyser off; D, E) sample Bad-1/47.40 m, analyser off; F) sample Bad2/62.00 $\mathrm{m}$, analyser off. Mineral abbreviations are the same as in Table 1.

grains, very rarely as idiomorphic, prismatic grains (Fig. 5 A). Amphiboles are pale green to brownish green prismatic crystals with expressed prismatic cleavage.

\subsection{Analyses of the sandy fraction $(0.90-1.25 \mathrm{~mm})$ and sandy-gravelly fraction $(1.25-2.80 \mathrm{~mm})$}

\section{Sample Bad-1/9.00 m}

In the sand and sandy to gravelly fractions of the investigated sample Bad-1/9.00 m particles of the rocks from greenschist facies prevail. They are represented by metabasic rocks rich in the epidote-actinolite-plagioclase mineral assemblage. More com- mon are various varieties of quartzite (synmetamorphic quartz mainly) (Figs. 6 A, B). Particles of black metapelites and metapsammites are less abundant. Micrite to microsparite carbonate particles are also rare. These carbonate particles differ from carbonate particles found at deeper levels and their possible origin could very likely be correlated to Cretaceous (?) limestones from the area.

\section{Sample Bad-1/15.00 m}

The sample Bad-1/15.00 m of the sand and sandy to gravelly fractions dominantly consist of black metapelites and metapsam- 

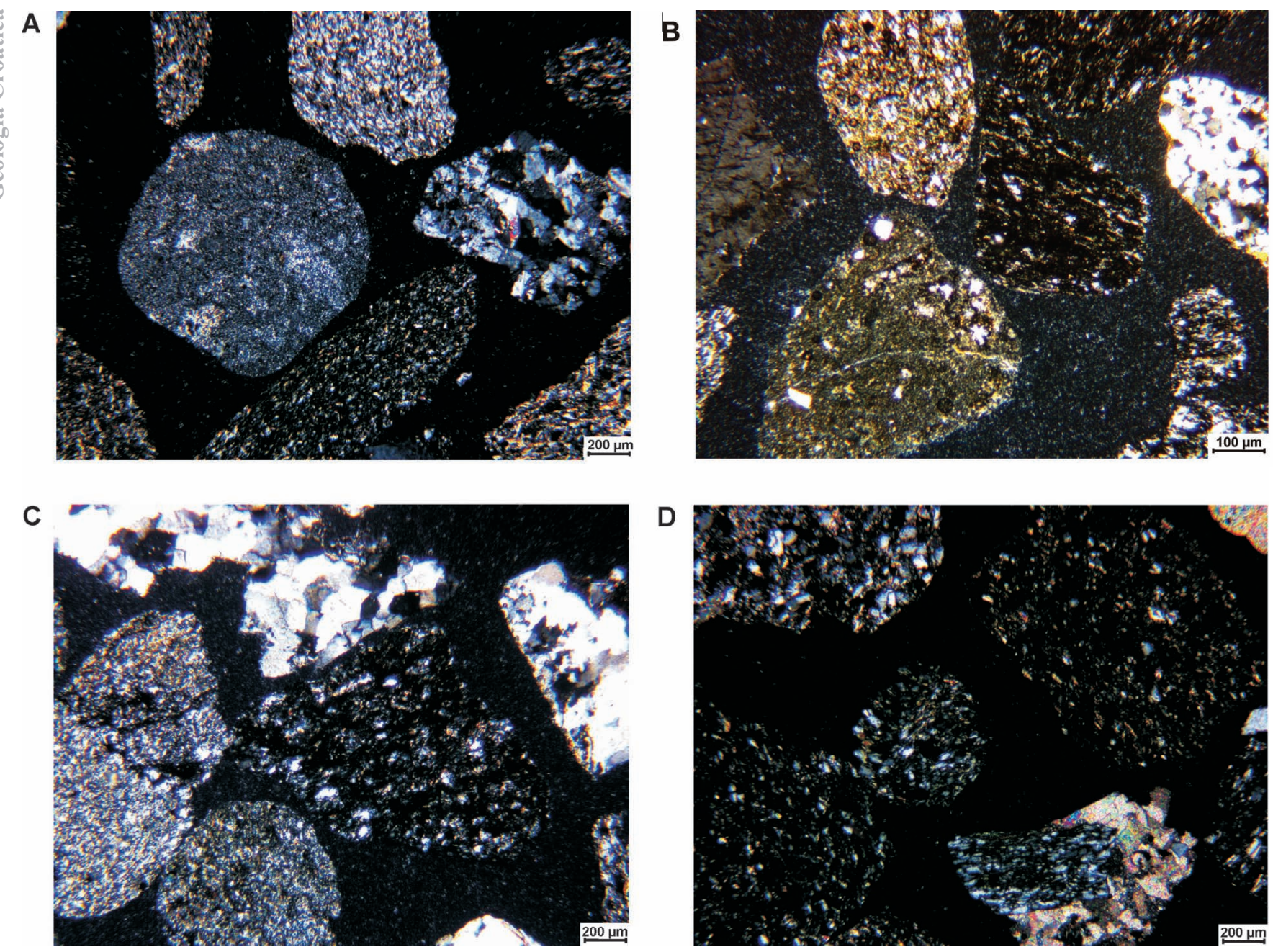

Figure 6. Photomicrographs of the sand and sandy to gravelly fraction aggregates of the investigated samples: A, B) Sample Bad-1/9.00 m; C, D) Sample Bad$1 / 15.00 \mathrm{~m}$ (detailed description see in the text).

mites. Organic matter is the main component of these particles (which is visible macroscopically and microscopically) and depending on their degree of metamorphism they could be determined as meta-anthracite or graphite (?) Figs. 6 C, D. In addition, a large amount of quartz particles is present (synmetamorphic quartz) (Figs. 6 C). Sandstones and metasandstones without the organic matter and carbonate particles (represented by recrystallized limestone fragments or marble) are not so common. The sand fraction of the investigated sample contains two goethite particles. Only a few rock fragments belonging to the greenschist facies were discovered. They contain epidote, actinolite and plagioclase needles.

The composition of the HMF, (sandy fraction $0.90-1.25 \mathrm{~mm}$ and sandy-gravelly fraction $1.25-2.80 \mathrm{~mm}$ ) of the samples suggest that the source rocks were from the Medvednica Mt. Palaeozoic metamorphic rock forms the base structure and the most common rocks of Medvednica Mt. According to LUGOVIĆ et al. (2006) the greenschist facies which crops out on the southern slopes of the Medvednica Mt. consists of metabasites overlain by metasediments (metapelites, meta arenites, marbles, metatuffites). These rocks were the main source of material for clastic rocks from Badel-1 and Badel-2 boreholes as well as the informal Bistra Formation. Amphibolite and chloritoid schists, metagabbros, metadiabases, slates, phyllites, dolomites, limestones, radiolarian cherts, pyroclastics, magmatic and different clastic sedimentary rocks, which are also present on Medvednica Mt. (ŠIKIĆ et al.,
1977; 1979, ŠIKIĆ, 1995; BASCH, 1983a, 1983b; HERAK, 2006) contributed in a minor amount as parent rocks to the informal Bistra Formation.

\subsection{Palynology}

Four samples for pollen analysis (three from Badel-1 at $9.70 \mathrm{~m}$, $58.20 \mathrm{~m}$ and $59.00 \mathrm{~m}$ depth, and one from Badel-2 at $18.40 \mathrm{~m}$ depth) were taken from the fine-grained samples, (i.e. silt and clay) containing more or less organic components. The main characteristic of the analyzed samples is the absolute dominance of the structured phytoclasts in the total organic residue that indicates a pronounced fluvial input of terrestrial organic components, and relatively short transport based on the structure, angularity and size of the organic clasts. Mechanical damage of the palynomorphs is the consequence of redeposition of older sediments (mainly Miocene). Such redeposition is common in glacial environments (BIRKS \& BIRKS, 1980), when redeposited palynomorphs from eroded interglacial deposits are observed in silt and clay together with Quaternary palynomorphs.

All samples contain palynomorphs (Tab. 2; Fig. 7). A minimum of 200 palynomorphs couldn't be reached only in Badel-1/9.70 m because there wasn't enough organic residue. Unfortunately, pollen concentration wasn't measured because the first intention was to check the environment and when material became promising palynomorphs were counted. The degree of preservation of the grains is medium to good, i.e. some grains' 
Table 2. Distribution of palynomorphs.

\begin{tabular}{|c|c|c|c|c|c|c|c|c|}
\hline \multirow{2}{*}{$\begin{array}{l}\text { sample: } \\
\text { palynomorphs: }\end{array}$} & \multicolumn{2}{|c|}{$\begin{array}{c}\text { Badel-1 } \\
9.7 \mathrm{~m}\end{array}$} & \multicolumn{2}{|c|}{$\begin{array}{c}\text { Badel-1 } \\
58.2 \mathrm{~m}\end{array}$} & \multicolumn{2}{|c|}{$\begin{array}{c}\text { Badel-1 } \\
59.0 \mathrm{~m}\end{array}$} & \multicolumn{2}{|c|}{$\begin{array}{c}\text { Badel-2 } \\
18.4 \mathrm{~m}\end{array}$} \\
\hline & $A$ & $\mathrm{~B}(\%)$ & $A$ & $\mathrm{~B}(\%)$ & $A$ & $B(\%)$ & $A$ & $\mathrm{~B}(\%)$ \\
\hline Polypodium & 5 & 10 & 26 & 13 & 22 & 6 & & \\
\hline Pteridium & & & 1 & 0 & 6 & 2 & & \\
\hline Sphagnum & & & & & 7 & 2 & & \\
\hline Lycopodium & & & 8 & 4 & 2 & 1 & & \\
\hline Bisaccites gen et sp indet. & 10 & 19 & 11 & 5 & 7 & 2 & 25 & 7 \\
\hline Pinus & 19 & 37 & 106 & 52 & 225 & 66 & 153 & 43 \\
\hline Picea & & & 13 & 6 & 22 & 6 & 24 & 7 \\
\hline Larix & 2 & 4 & 3 & 1 & 11 & 3 & 5 & 1 \\
\hline Quercus & 5 & 10 & & & & & 1 & 0 \\
\hline Graminae & 2 & 4 & 2 & 1 & 2 & 1 & 6 & 2 \\
\hline Asteraceae & 1 & 2 & 4 & 2 & 4 & 1 & 7 & 2 \\
\hline Cichoriaceae & & & & & 3 & 1 & 6 & 2 \\
\hline Cyperaceae & 1 & 2 & 9 & 4 & & & 83 & 23 \\
\hline Caryophyllaceae & & & & & & & 2 & 1 \\
\hline Mimosaceae & & & & & & & 4 & 1 \\
\hline Sigmopollis & & & & & 3 & 1 & 12 & 3 \\
\hline Zygnema & & & & & 1 & 0 & 6 & 2 \\
\hline Spirogyra & & & & & 3 & 1 & 11 & 3 \\
\hline Mougeotia & & & 1 & 0 & & & & \\
\hline Tilletia & 1 & 2 & & & & & & \\
\hline Dinocyst & 4 & 8 & 5 & 2 & & & 1 & 0 \\
\hline unknown & 2 & 4 & 15 & 7 & 21 & 6 & 13 & 4 \\
\hline total palynomorphs sum & 52 & 100 & 204 & 100 & 339 & 100 & 359 & 100 \\
\hline
\end{tabular}

Columns A - Number of identified palynomorphs per samples

Columns B - Percentages of palynomorphs per samples

structure and sculpture are partially destroyed making more precise determination impossible. The plant community is relatively poor in species. The Polypodium-type is among the most resistant sporomorphs to corrosion, containing the most sporopollenin (HAVINGA, 1964, 1984), and therefore it is common in samples that are scarce in palynomorphs. Tertiary relicts (e.g. Carya whose pollen is very resistant), except redeposited forms, were not observed, which could indicate that the samples are probably of the younger Pleistocene age. Frigophile vegetation indicates a cold period. Since the cold stage flora is quite uniform (ŠERCELJ, 1979) it is difficult to classify the deposits to particular glacial, and/or stadial, in the case when they are not linked to the previous or following warmer period.

The oldest sample from the core Badel-1 at $59.00 \mathrm{~m}$ is dominated by conifer pollen. Pinus, the most abundant (68\%), and $\mathrm{Pi}$ cea $(6 \%)$ were brought in the depositional environment by wind or streams. Less abundant is fern Polypodium-type (6\%) and moss Sphagnum (2\%) spores that prevailed in the acidified $(\mathrm{pH}$ 3-4) mires belonging to the boreal floral element. Boreal mires favour a moderately cold and humid climate, so when the ice started to melt after the last Ice Age in Europe, 10000 years ago, it covered a huge area. Wetter weather and higher sea levels combined to raise groundwater tables everywhere, so that large mires arose in poorly drained lowlands and basins (RAEYMAEKERS,
2000). Spores of the planktonic algae Sigmopollis are an indicator of the slowly-moving shallow eutrophic to mesotrophic fresh water environment (PALS et al., 1980, VAN GEEL et al., 1989). Due to vegetational succession, boreal mires alter to heathland. In the sample Badel-1/58.20 m the moss genus Sphagnum and algae Sigmopollis completely disappear, conifer Pinus decrease (52\%) while the share of Polypodium-type fern increases (13\%). Redeposited dinocysts (2\%) confirm erosion of the older sediments (i.e. Miocene). Sample Badel-1/9.70 m from the upper part of the core contains a very small amount of organic residue of a mixed composition. Sporomorphs are rare with only 52 specimens: conifer (56\%), fern spore Polypodium-type (10\%), Quercus (10\%), Graminae, Cyperaceae pollen, Larix, and redeposited dinoflagellate cysts (Polysphaeridium) were determined, indicating open vegetation, erosion and deposition on the floodplain. Similar vegetation was also growing around Lake Bled during the Younger Dryas (ANDRIČ et al, 2009).

In Badel-2 only one sample was analyzed from $18.40 \mathrm{~m}$ deep. It is also dominated by conifer pollen (43\%) and Cyperaceae $(23 \%)$ but the proportion of algae $(8 \%)$ is significant. The occurrence of zygospores of Spirogyra, Zygnema and Mougeotia in the Quaternary deposits indicates a shallow eutrophic water body with warm pluvial periods which supplied fluvial sediments (MEDEANIC, 2006, VAN GEEL et al., 1989, WOROBIEC, 2014). In the Zygnemataceae, zygospore formation occurs mostly during the spring season in clean, oxygen-rich, shallow fresh water (VAN GEEL, 1976). The optimal temperature for Zygnema is $15-20^{\circ} \mathrm{C}$, and for most species of Spirogyra the optimum is $14-22^{\circ} \mathrm{C}$ (HOSHAW, 1968). Such high temperatures are easily reached in shallow water exposed to direct solar radiation, at least during the warm season (VAN GEEL, 1978). A pH value of 7.0-8.0 was inferred from the zygospores of Spirogyra (GROTE, 1977). Spores of the planktonic algae Sigmopollis (22\%) are an indicator of meso-oligotrophic slower stream to calm water environments (VAN GEEL et al., 1989). The alga Mougeotia is one of the most common freshwater algae, and is common from arctic to tropical areas, in lakes, springs and streams, and even in occasional ponds, where it appears as the first alga after the rainy season (TRANSEAU, 1926). Zygnemataceae, especially Mougeotia, dominate in acidic lakes (TURNER et al., 1995; GRAHAM et al., 1996).

According to the Köppen's classification, the climate was most likely humid boreal (Df) during deposition of samples Badel-1/58.20 m, Badel-1/59.00 m and Badel-2/18.40 m and dry boreal (Dw) during the deposition of sample Badel-1/9.70 m (ŠEGOTA \& FILIPČIĆ, 2003).

\subsection{Origin of vivianite}

The occurrence of vivianite in sediments of the informal Bistra Formation is not a ubiquitous occurrence and it is not indicative for these deposits according to field investigations during geological mapping. One of the most important factors of vivianite formation is a sufficiently high concentration of orthophospate and $\mathrm{Fe}^{2+}$ in the pore waters (NRIAGU, 1972). The presence of limonite and magnetite in the HMF of sandy and silty fractions, Fe-Mn concretions in sediments as a source of Fe phases, high content of phosphorus (P) in stream sediments of some creeks from Medvednica Mt. (GALOVIĆ et al., 2012), and reducing conditions, as seen from the gray colour of sediments and palynomorphs of the investigated samples were some of the prerequisites for vivianite formation. A variety of factors are of primary importance and may affect vivianite formation as well, such as redox conditions, deg- 


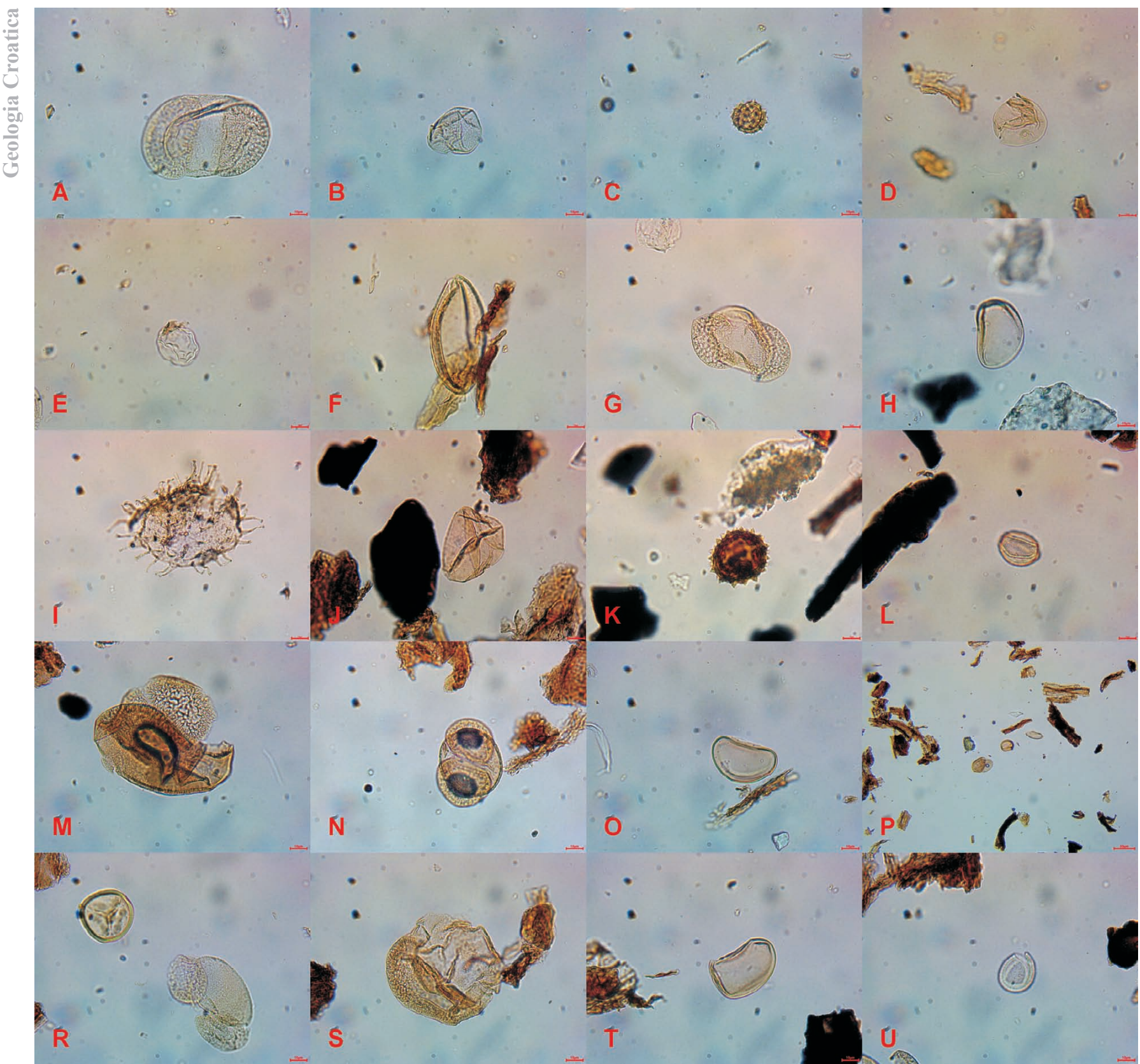

Figure 7. Photomicrograph of determined palynomorphs: Badel-2/18.40 m: A) Pinus, B) Cyperaceae, C) Asteraceae, D) Graminae, E) Zygnema, F) Spirogyra; Badel-1/9.70 m: G) Pinus, H) Polypodium-Type, I) Polysphaeridium, J) Cyperaceae, K) Asteraceae, L) Quercus; Badel-1/58.20 m: M) Picea, N) Pinus, O) Polypodium-Type, P) Phytoclasts and Badel-1/59.00 m: R) Sphagnum and Pinus, S) Picea, T) Polypodium-Type, U) Sigmopollis. Scale Bar $=10 \mu \mathrm{m}$ except on P) $=50 \mu \mathrm{m}$.

radation potential of organic matter, microbial community composition, resorption potential by remaining Fe(III) (oxyhydr)oxides and silicate clays, orthophosphate release, temperature and $\mathrm{pH}$ (ROTHE et al., 2016). It is obvious that if some of the above mentioned factors are not present, vivianite will not occur. Additionally, there is the possibility that a very small amount of vivianite present in the sample/sediment cannot be detected.

Although vivianite has been detected in many anthropogenically influenced sedimentary settings (GOSLAR et al., 1999; ROTHE et al., 2015, 2016), in the case of the analyzed samples such influence is hardly possible. One of the reasons is low clayey silts water permeability above the horizons in which vivianite occurres (Fig. 3). Another reason could be that in many freshwater systems, an increased nutrient supply led to accelerated eutrophication, a change in oxygen and redox conditions and the appea- rance of $\mathrm{S}^{2-}$ in the water column, indicating a loss of $\mathrm{Fe}$ and $\mathrm{P}$ binding capacity of the sediments (ROTHE et al., 2016). According to ROTHE et al. (2015), vivianite is in some cases present only in pre-industrial sediments with low ranges of nutrient levels, organic matter production and sulphur supply during its deposition. In the area of Zagreb, vivianite nodules were recorded in another borehole near the „DIOKI” factory at $44.80 \mathrm{~m}$ depth (unpublished data). The presence of vivianite in deep sediment layers demonstrates that vivianite can persist for many thousands of years within the sediments (ROTHE et al., 2016).

\section{CONCLUSION}

Analysed Quaternary sediments from boreholes Badel-1 and Badel-2 were grouped into three facies deposited in alluvial environment: 
1) gravel and sand deposits typical of alluvial environments

2) structureless beds of silts and clays deposited in oxbow lakes, marshes and on floodplains

3) chaotic sediments deposited in the upper part of the alluvial fan.

Below the first two facies at a depth up to 15.20 m earthy aggregates and nodules of vivianite were determined. SEM analyses revealed flattened crystal clusters up to $6 \mu \mathrm{m}$ length. Vivianite occurrence is associated with the presence of limonite, magnetite and Fe-Mn concretions in sediments as a source of Fe phases, a high content of phosphorus $(\mathrm{P})$ in the stream sediments of some creeks from Medvednica Mt., and reducing conditions as suggested by the palynomorphs of the investigated samples.

Deposition of the sediments based on the samples analysed for palynology (from sediments both underlying and overlying those with vivianite) most probably occurred in a marshy environment (Badel-2/18.40 m; Badel-1/59.00 m; Badel-1/58.20 m) with periodic fluvial input of terrestrial organic components, as well as on sandbanks and wet meadows on a floodplain (Badel-1/9.70 m). According to the Köppen classification, based on palynology, the climate was most likely humid boreal (Df) during deposition of samples Badel-1/58.20 m, Badel-1/59.00 m and Badel-2/18.40 $\mathrm{m}$ and dry boreal (Dw) during deposition of the sample Badel-1/9.70 m.

\section{ACKNOWLEDGEMENT}

This study was supported by the Ministry of Science, Education and Sports, Republic of Croatia, Project No. 181-1811096-1093 and the Croatian Science Foundation Project No. 4425. We are very thankful to Branko HLEVNJAK (University of Zagreb, Faculty of Mining, Geology and Petroleum Engineering) for access to the borehole sediments. Special thanks also go to Mirko BELAK (Croatian Geological Survey) for the discussion on the origin of the material and Dario HRUŠEVAR for discussion on vegetation cover. We appreciated the contributions by Nenad TOMAŠIĆ (University of Zagreb, Faculty of Science) for graphite coating and processing of the samples for SEM-EDS analysis, Nenad KURTANJEK for preparing Fig. 1., Vlasta JURIŠIĆ MITROVIĆ for chemical treatments, Mirjana DRUŠKOVIĆ, Dragica KOVAČIĆ, Antun ŠKRTIĆ and Damir GALOVIĆ (Croatian Geological Survey) for sample preparation. Language editing was undertaken by Lara WACHA and Zoran PEH (Croatian Geological Survey) and Language Editor Julie ROBSON which has improved the quality of expression, for which we thank them. We are very grateful to Maja ANDRIČ, Davor PAVELIĆ and an anonymous reviewer for their valuable and helpful comments.

\section{REFERENCES}

ANDRIČ, M., MASSAFERRO, J., EICHER, U., AMMANN, B., LEUENBERGER, M.C., MARTINČIČ, A., MARINOVA, E. \& BRANCELJ, A. (2009): A multiproxy Lateglacial palaeoenvironmental record from Lake Bled, Slovenia.- Hydrobiologia, 631, 121-141.

AVANIĆ, R., BAKRAČ, K., GRIZELJ, A., WACHA, L., ŠIMIĆ-STANKOVIĆ, M., HEĆIMOVIĆ, LJ., TIBLJAŠ, D. \& KRUK, B. (2006): Ivošević Gaj ceramic clay deposit in the vicinity of Vojnić.- In: VLAHOVIĆ, I., TIBLJAŠ, D. \& DURN, G. (eds.): 3rd Mid-European Clay Conference, Opatija, Field Trip Guidebook, 39-47.

AVANIĆ, R., KOVAČIĆ, M., PAVELIĆ, D., MIKNIĆ, M., VRSALJKO, D., BAKRAČ, K., GALOVIĆ, I. (2003): The Midle and Upper Miocene facies of Mt. Medvednica (Northern Croatia).- In: VLAHOVIĆ, I. \& TIŠLJAR, J. (eds.): Evolution of Depositional Environments from Paleozoik to the Quarternary in the Karst Dinarides and the Pannonian Basin, $22^{\text {nd }}$ IAS Meeting of Sedimentology.Opatija, Field Trip Guidebook, 167-172.

BABIĆ, LJ., HOCHULI, P.A. \& ZUPANIČ, J. (2002): The Jurassic ophiolitic melange in the NE Dinarides: Dating, internal structure and geotectonic implications.Eclogae geologicae Helvetiae, 95, 263-275.
BASCH, O. (1983a): Osnovna geološka karta SFRJ 1:100000, list Ivanić Grad L33-81 [Basic Geological Map of SFRY, 1:100000. Ivanić Grad sheet - in Croatian].Geološki zavod Zagreb, Savezni geološki zavod Beograd.

BASCH, O. (1983b): Osnovna geološka karta SFRJ 1:100000, Tumač za list Ivanić Grad [Basic Geological Map of SFRY, 1:100000, Geology of the Ivanić Grad sheet-in Croatian].- Geološki zavod Zagreb, Savezni geološki zavod Beograd, 66 p.

BELAK, M. \& TIBLJAŠ, D. (1998): Discovery of blueschists in the Medvednica Mountain (Northern Croatia) and their significance for the interpretation of the geotectonic evolution of the area.- Geol. Croatica, 51/1, 27-32. doi: 10.4154/GC.1998.05

BELAK, M., PAMIĆ, J., KOLAR-JURKOVŠEK, T., PECKAY, Z. \& KARAN, D. (1995): Alpinski regionalmetamorfni kompleks Medvednice (sjeverozapadna Hrvatska).- In: VLAHOVIĆ, I., VELIĆ, I. \& ŠPARICA, M. (eds.): 1st Croatian Geologic Congress, Opatija, Proceedings, 1, 67-70.

BERMANEC, V. (1999): Sistematska mineralogija - mineralogija nesilikata [System of Mineralogy - Silicate Minerals - in Croatian].- Targa, Zagreb, 264 p.

BERNER, R.A. (1981): A new geochemical classification of sedimentary environments.J. Sediment. Res., 51, 359-365.

BIRKS, H.J.B \& BIRKS, H.H. (1980): Quaternary Palaeoecology.- (Reprinted 2004 by the Blackburn Press, New Jersey) Edward Arnold, London.

BRLEK, M., ŠPIŠIĆ, M., BRČIĆ, V., MIŠUR, I. KUREČIĆ, T., MIKNIĆ, M., AVANIĆ, R., VRSALJKO, D. \& SLOVENEC, D. (2016): Mid-Miocene (Badenian) transgression on Mesozoic basement rocks in the Mt. Medvednica area of northern Croatia.- Facies 62/3, 1-21. doi: 10.1007/s10347-016-0470-z.

ĆORIĆ, S., PAVELIĆ, D., RÖGL, F., MANDIĆ, O., VRABAC, S., AVANIĆ, R. \& VRANJKOVIĆ, A. (2009): Revised Middle Miocene datum for initial marine flooding of North Croatian Basins (Pannonian Basin System, Central Paratethys).Geologia Croatica, 62, 31-43. doi: 10.4154/GC.2009.03

CRNKOVIĆ, B. \& BUŠIĆ, M. (1970): Mineraloško-petrografski nanos rijeke Save. [Mineralogical-petrological sediments of river Sava - in Croatian].- Zbornik radova Rud. Geol. Naftnog fakulteta. Sveučilišta u Zagrebu u povodu 30 god. rada (1939-1969). 133-140.

CROATIAN GEOLOGICAL SURVEY (2009): Geological Map of the Republic of Croatia 1:300000.- Department of Geology, Zagreb.

FAEGRI, K. \& IVERSEN, J. (1989): Textbook of Pollen Analysis. (4th Edition by FAEGRI, K., KALAND, P.E. \& KRZYWINSKI, K. (eds.).- John Wiley \& Sons New York, $328 \mathrm{p}$.

GALOVIĆ, L., PEH, Z., HALAMIĆ, J. \& BUKOVEC, D. (2012): Geochemical atlas of the Medvednica Mt.: natural distribution of geochemical elements in stream sediments.- Journal of Maps, 8/4, 478-483. doi: 10.1080/17445647.2012.741833.

GORJANOVIĆ-KRAMBERGER, D. (1907): Dali je gora bila Zagrebačka odleđena i kako je postala Zagrebačka terasa [Was the Zagreb Mt. thawed and how the Zagreb terasa originate - in Croatian].- Glasn. Hrv. Naravosl. Društva, 19, 37-43.

GOSLAR, T., RALSKA-JASIEWICZOWA, M., VAN GEEL, B., ŁACKA, B., SZEROCZYŃSKA, K., CHRÓST, L. \& WALANUS, A. (1999): Anthropogenic changes in the sediment composition of Lake Gościąż (central Poland), during the last 330 yrs*.- Journal of Paleolimnology, 22, 171-185.

GROTE, M. (1977): Über die Auslösung der generativen Fortpflanzung unter kontrollierten Bedingungen bei der Grünalge Spirogyra majuscule.- Z-Pflanzenphysiol., 83, 95-107.

GRAHAM, J.M., ARANCIBIA-AVILA, P. \& GRAHAM, L.E. (1996): Physiological Ecology of a Species of the Filamentous Green Alga Mougeotia Under Acidic Conditions: Light and Temperature Effects on Photosynthesis and Respiration.Limnology and Oceanography, 41/2, 253-262.

GRIZELJ, A., PEH, Z., TIBLJAŠ, D., KOVAČIĆ, M. \& KUREČIĆ, T. (2017): Mineralogical and geochemical characteristics of Miocene pelitic sedimentary rocks from the south-western part of the Pannonian Basin System (Croatia): Implications for provenance studies.- Geoscience Frontiers, 811, 65-80. doi: 10.1016/j.gsf.2015.11.009

HARZHAUSER, M \& PILLER, W.E. (2007): Benchmark dana of a changing sea - Paleogeography, Paleobiogeography and events in the Central Paratethys during the Miocene.- Paleogeogr. paleoclimatol. paleoecol., 253, 8-31.

HAAS, J. \& KOVÁCS, S. (2001): The Dinaridic-Alpine connection - as seen from Hungary.-Acta Geol. Hung., 44, 345-362.

HAAS, J., MIOČ, P., PAMIĆ, J., TOMLJENOVIĆ, B., ÁRKAI, P., BÉRCZI-MAKK, A., KOROKNA, I. B., KOVÁCS, S. \& R.-FELGENHAUER, E. (2000): Complex structural pattern of the Alpine-Dinaridic Pannonian triple junction.- Int. J. Earth Sci., 89, 377-389. doi: 10.1007/s005310000093

HALAMIĆ, J. \& GORIČAN, Š. (1995): Triassic radiolarites from Mts. Kalnik and Medvednica (northwestern Croatia).- Geologia Croatica, 48/2, 129-146. doi: 10.4154/ GC. 1995.10

HALAMIĆ, J., GORIČAN, Š., SLOVENEC, D. \& KOLAR-JURKOVŠEK, T. (1999): A Middle jurassic radiolarites-clastic succession from the Medvednica Mt., NW Croatia.- Geologia Croatica, 52/1, 29-57. doi: 10.4154/GC.1999.03

HAVINGA, A.J. (1964): An investigation into the differential corrosion susceptibility of pollen and spores.- Pollen Spores, 6, 621-635.

HAVINGA, A.J. (1984): A 20 -year experimental investigation into the differential corrosion susceptibility of pollen and spores in various soil types.- Pollen Spores, 26, $541-558$. 
HERAK (1999): Tectonic interrelation of the Dinarides and the Southern Alps.- Geol. Croatica, 52, 83-98. doi: 10.4154/GC.1999.07

HERAK, M. (2006): Medvednica. Zagonetno zagrebačko gorje [Enigmatic Zagreb Mountains - in Croatian, English summary].- Hrvatski geološki institut, Zagreb, $195 \mathrm{p}$.

HORVATH, F. \& ROYDEN, L.H. (1981): Mechanism for the Formation of the IntraCarpathian Basins: A Review.- Earth Science Reviews, 3-4, 307-316.

HOSHAW R.W. (1968): Biology of the filamentous conjugating algae.- In: JACKSON D.F. (ed.): Algae, Man and Environment. Syracuse University Press, 135-184.

KONTA, I. (1973): Kvantitativní systém reziduálních hornin, sedimentů a vulkanoklastických usazenin. [Quantitative system of residual rocks, sediments and volcanoclastic deposits - in Czech].- Univ. Karlova, Praha, 1-375.

KOVAČIĆ, M. \& GRIZELJ, A. (2006): Provenance of the Upper Miocene clastic material in the southwestern part of the Pannonian Basin.- Geologica Carpathica, 57/6, 495-510.

LUGOVIĆ, B., ŠEGVIĆ, B. \& ALTHERR, R. (2006): Petrology, geochemistry and tectonic significance of the orthogreenschists from the SW Zagorje-Mid-Transdanubian Zone (Medvednica Mts, Croatia).- Ofioliti, 39/1, 31-50.

MENGE, M.A. \& MAURER, H.F.W. (1992): Heavy Minerals in Colour-- Chapman \& Hall, London, 1-151. doi: 10.1007/978-94-011-2308-2

MEDEANIC, S. (2006): Freshwater algal palynomorph records from Holocene deposits in the coastal plain of Rio Grande do Sul, Brazil.- Rev. Palaeobot. Palynol., 141, 83-101. doi: 10.1016/j.revpalbo.2006.03.012

MIALL, A.D. (1996): The Geology of Fluvial Deposits. Sedimentary Facies, Basin Analysis and Petroleum Geology.- Springer-Verlag, Heidelberg, $582 \mathrm{p}$.

MIALL, A.D. (2000): Principles of Sedimentary basin Analysis.-3rd ed., Springer-Verlag, Berlin-Heidelberg, 616 p. doi: 10.1007/978-3-662-03999-1

MOORE, P.D., WEBB, J.A. \& COLLINSON, M. (1991): Pollen Analysis (second edition).- Blackwell Sci. Publication, London, $216 \mathrm{p}$.

NEMEC, W. \& KAZANCI, N. (1999): Quaternary colluvium in west-central Anatolia: sedimentary facies and palaeoclimatic significance.-Sedimentology, 46, 139-170. doi: 10.1046/j.1365-3091.1999.00210.x

NEMEC, W. \& POSTMA, G. (1993): Quaternary alluvial fans in southwestern Crete: sedimentation processes and geomorphic evolution.- In: MARZO, M. \& PUIGDEFÁBREGAS, C. (eds.): Alluvial sedimentation. IAS Spec. Publs, 17, 235-276. doi: 10.1002/9781444303995.ch18

NEMEC, W. \& STEEL, R.J. (1984): Alluvial and costal conglomerates: their significant features and some comments on gravelly mass-flow deposits.- In: COSTER, E.H. \& STEEL, R.J. (eds.): Sedimentology of gravels and conglomerates. Can. Soc. Petrol. Geologists Mem., 10, 1-31.

NRIAGU, J.O. (1972): Stability of vivianite and ion-pair formation in the system $\mathrm{Fe}_{3}\left(\mathrm{PO}_{4}\right)_{2}-\mathrm{H}_{3} \mathrm{PO}_{4}-\mathrm{H}_{2} \mathrm{O}$. - Geochim. Cosmochim. Acta, 36, 459-470.

PALS, J.P., VAN GEEL, B. \& DELFOS, A. (1980): Palaeocological studies in the Klokkeweel bog near Hoogkarspel (prov. of Noord Holland).- Rev. Palaeobot. Palynol., 30, 371-418.

PAMIĆ, J. (2002): The Sava-Vardar Zone of the Dinarides and Hellenides versus the Vardar ocean.- Eclogae Geol. Helv., 95, 99-113.

PAMIĆ, J. (2003): The allochthonous fragments of the Internal Dinaridic units in the western part of the South Pannonian Basin.- Acta Geol. Hung. 46, 41-62.

PAMIĆ, J. \& TOMLJENOVIĆ, B. (1998): Basic geologic data from the Croatian part of the Zagorje-Mid Transdanubian zone.- Acta Geol. Hung., 41, 389-400.

PAVELIĆ, D. (2001): Tectonostratigraphic model for North Croatian basin and North Bosnia (Miocene, Pannonian Basin System).- Basin Research, 13, 359-376.

PAVELIĆ, D., AVANIĆ, R., KOVAČIĆ, M., VRSALJKO, D. \& MIKNIĆ, M. (2003): An outline of the Evolution of the Croatian Part of the Pannonian Basin System.In: VLAHOVIĆ, I. \& TIŠLJAR, J. (eds.): $22^{\text {nd }}$ IAS Meeting of Sedimentology, Opatija, Field Trip Guidebook, 155-161.

RAEYMAEKERS, G. (2000): Conserving mires in the European Union. Actions co-financed by LIFE-Nature. Ecosystems Ltd, Luxembourg.

RODEN, E.E. \& EDMONDS, J.W. (1997): Phosphate mobilization in iron-rich anaerobic sediments: microbial Fe(III) oxide reduction versus iron-sulfide formation.Arch. Hydrobiol., 139, 347-378.

ROYDEN, L.H. (1988): Late Cenozoic Tectonics of the Pannonian Basin System.-- In ROYDEN, L.H. \& HORVATH, I.F. (eds.): The Pannonian Basin. A study in Basin Evolution (AAPG Memoir, Tulsa, 45, 27-48.

ROYDEN, L.H., HORVATH, F., NAGYMAROSY, A. \& STEGENA, L. (1983): Evolution of the Pannonian Basin System 2, Subsidence and thermal history.-Tectonics, 2, 91-137. doi: 10.1029/TC002i001p00091

ROTHE, M., FREDERICHS, T., EDER, M., KLEEBERG, A. \& HUPFER, M. (2014): Evidence for vivianite formation and its contribution to long-term phosphorus retention in a recent lake sediment: a novel analytical approach.- Biogeoscience, 11, 5169-5180. doi:10.5194/bg-11-5169-2014.

ROTHE, M., KLEEBERG, A., GRÜNEBERG, B., FRIESE, K., PÉREZ-MAYO, M. \& HUPFER, M. (2015): Sedimentary sulphur: Ratio indicates vivianite Occurrence: A study from two contrasting freshwater systems.- Plos one, 1-18. doi: 10.1371/ jurnal.phone.0143737.

ROTHE, M., KLEEBERG, A. \& HUPFER, M. (2016): The occurence, identification and environmental relevance of vivianite in waterlogged soils and aquatic sediments.-Earth-Science Reviews, 158, 51-64. doi: 10.1016/j.erscirev.2016.04.008.
ŠEGOTA, T. \& FILIPČIĆ, A. (2003): Köppenova podjela klima i hrvatsko nazivlje.Geoadria, 8/1, 17-37.

ŠERCELJ, A. (1979): Pregled Pleistocenske flore Jugoslavije.- In: BENAC, A. (ed.): Praistorija jugoslavenskih zemalja, sv. 1: Paleolit i mezolit [Prehistory of Yugoslav countries/Paleolithic and Mesolithic - in Croatian].- Akademija nauka i umjetnosti Bosne i Hercegovine, Sarajevo, 35-53.

ŠIKIĆ, K., BASCH, O. \& ŠIMUNIĆ, AN. (1977): Osnovna geološka karta SFRJ 1:100.000. List Zagreb, L 33-80 [Basic Geological Map of SFRY, 1:100000. Zagreb sheet - in Croatian].- Institut za geološka istraživanja Zagreb, Savezni geološki zavod Beograd.

ŠIKIĆ, K., BASCH, O. \& ŠIMUNIĆ, AN. (1979): Osnovna geološka karta SFRJ 1:100.000. Tumač za list Zagreb [Basic Geological Map of SFRY, 1:100000, Geology of the Zagreb sheet - in Croatian].- Institut za geološka istraživanja Zagreb, Savezni geološki zavod Beograd, $81 \mathrm{p}$.

ŠIKIĆ, K. (1995): Prikaz geološke građe Medvednice. [Review of structure of the Medvednica Mt. - in Croatian].- In: ŠIKIĆ, K. (ed.): Geološki vodič Medvednice. Institut za geološka istraživanja, Ina industrija nafte d.d., Zagreb, 5-30.

ŠIMUNIĆ, A. \& BASCH, O. (1975): Stratigrafija kvartarnih sedimenata zagrebačkog Posavlja [Stratigraphy of Quaternary sediments of Zagreb Posavlje - in Croatian].- Geol. vjesnik, 28, 153-164.

ŠIMUNIĆ, A., NOVOSEL-ŠKORIĆ, S. \& PILJUROVIĆ, LJ. (1988): Litološka korelacija i kronostratigrafsko razgraničavanje kvartarnih naslaga na lokalitetu Prevlaka jugoistočno od Zagreba. [Chronostratigraphic subdivision of Quaternaty sediments from the location Prevlaka Southern from Zagreb - in Croatian, English summary].- Geološki vjesnik, 41, 167-179.

SLOVENEC, D. \& LUGOVIĆ, B. (2008): Amphibole gabbroic rocks from the Mt. Medvednica ophiolite mélange (NW Croatia): geochemistry and tectonic setting.- Geologica Carpathica, 59/4; 277-293.

SLOVENEC, D. \& LUGOVIĆ, B. (2009): Geochemistry and tectono-magmatic affinity of mafic extrusive and dyke rocks from the ophiolite melange in the SW Zagorje-Mid-Transdanubian Zone (Mt. Medvednica, Croatia).- Ofioliti 34/1, 63-80.

SLOVENEC, D. \& LUGOVIĆ, B. (2012): Evidence of the spreading culmination in the Eastern Tethyan Repno oceanic domain assessed by the petrology and geochemistry of N-MORB extrusive rocks from the Mt. Medvednica ophiolite mélange (NW Croatia).- Geologia Croatica, 65/3, 435-446. doi: 10.4154/GC.2012.32

TOMLJENOVIĆ, B., CSONTOS, L. MÁRTON, E. \& MÁRTON, P. (2008): Tectonic evolution of the northwestern Internal Dinarides as constrained by structures and rotation of Medvednica Mountains, North Croatia, Geol.- Soc. London, Spec. Publ., 298/1, 145-167.

TRANSEAU, E.N. (1926): The Genus Mougeotia.- The Ohio Journal of Science, v.26, n.6, 311-338.

TREFETHEN, J.M. (1950): Classification of sediments.- Am. J. Sci., 248, 55-62.

TURNER, M.A., ROBINSON, G.G.C., TOWNSEND, B.E., HANN, B.J., AMARAL, J.A. (1995): ,Ecological effects of blooms of filamentous green algae in the littoral zone of an acid lake".- Canadian Journal of Fisheries and Aquatic Sciences, 52, 2264-2275.

VAN GEEL, B. (1976): Fossil spores of Zygnemataceae in ditches of a prehistoric settlement in Hoogkarspel (The Netherlands).- Rev. Palaeobot. Palynol., 22, 337-344.

VAN GEEL, B. (1978): A palaeoecological study of Holocene peat bog sections in Germany and the Netherlands, based on the analysis of pollen, spores and macro- and microscopic remains of fungi, algae, cormophytes and animals.- Rev. Palaeobot. Palynol., 25, 1-120. doi: 10.1016/0034-6667(78)90040-4

VAN GEEL, B., COOPE, G.R. \& VAN DER HAMMEN, T. (1989): Palaeoecology and stratigraphy of the Lateglacial type section at Usselo (The Netherlands).- Rev. Palaeobot. Palynol., 60, 25-129. doi: 10.1016/0034-6667(89)90072-9

VELIĆ, J. \& DURN, G. (1993): Alternating Lacustrine-Marsh Sedimentation and Subaerial Exposure Phases During Quaternary: Prečo, Zagreb, Croatia.- Geologia Croatica, 46/1, 71-90. doi: 10.4154/GC.1993.06

VELIĆ, J., TADEJ, N., DURN, G. \& SAFTIĆ, B.(1995): Genesis of Quaternary deposits in the area of Zagreb and surroundings of Samobor-- In: VLAHOVIĆ, I., VELIĆ, I. \& ŠPARICA, M. (eds.): First Croatian Geological Congress, Opatija, Abstracts, p. 97.

VELIĆ, J., SAFTIĆ, B. \& MALVIĆ, T. (1999): Lithological Composition and Stratigraphy of Quaternary Sediments in the Area of the ,Jakuševec" Waste Depository (Zagreb, Northern Croatia).- Geologia Croatica, 52/2, 119-130. doi: 10.4154/ GC.1999.10

VRSALJKO, D. (1999): The Pannonian paleoecology and biostratigraphy of mollusca from Kostanjek-Medvednica Mt.Croatia.- Geologia Croatica, 52/1, 9-27. doi: 10.4154/GC.1999.02

VRSALJKO, D., PAVELIĆ, D., MIKNIĆ, M., BRKIĆ, M., KOVAČIĆ, M., HEĆIMOVIĆ, I., HAJEK-TADDESE, V., AVANIĆ, R., KURTANJEK, K. (2006): Middle Miocene (Upper Badenian/Sarmatian) paleoecology and evolution of the environments in the area of Medvednica Mt. (North Croatia).- Geologia Croatica, 59/1, 51-63. doi: $10.4154 / \mathrm{GC} .2006 .04$

WOROBIEC, E. (2014): Fossil zygospores of Zygnemataceae and other microremains of freshwater algae from two Miocene palaeosinkholes in the Opole region, SW Poland.- Acta Palaeobotanica, 54/1,113-157. doi: 10.2478/acpa-2014-0005 